\title{
The prognostic value of pre-treatment thrombocytosis in two cohorts of patients with non-small cell lung cancer treated with curatively intended chemoradiotherapy
}

\author{
G. HOLGERSSON ${ }^{1,2, \star}$, S. BERGSTROM ${ }^{1,2}$, A. HALLQVIST ${ }^{3}$, P. LIV $^{1}$, J. NILSSON ${ }^{1,4}$, L. WILLEN ${ }^{1,4}$, J. NYMAN NY S. EKMAN $^{5}$, R. HENRIKSSON ${ }^{4}$, \\ M. BERGQVIST ${ }^{1,4}$
}

${ }^{1}$ Center for Research \& Development, Uppsala University/ County Council of Gävleborg, Gävle Hospital, SE-801 87 Gävle, Sweden; ${ }^{2}$ Department of Immunology, Genetics and Pathology, Uppsala University Hospital, SE-751 85 Uppsala, Sweden; ${ }^{3}$ Department of Oncology, Sahlgrenska University Hospital, SE- 41345 Göteborg, Sweden; ${ }^{4}$ Department of Radiation Sciences \& Oncology, Umeå University Hospital, SE-901 87 Umeå, Sweden; ${ }^{5}$ Department of Oncology, Karolinska University Hospital, SE-171 76 Stockholm, Sweden

${ }^{*}$ Correspondence: georg.holgersson@regiongavleborg.se

Received December 29, 2016 / Accepted April 3, 2017

\begin{abstract}
Chemoradiotherapy is the standard of care for inoperable stage III non-small cell lung cancer (NSCLC). This treatment, however, offers only a small chance of cure and is associated with many side effects. Little research has been made concerning which patients benefit most/least from the treatment. The present study evaluates the prognostic value of anemia, leukocytosis and thrombocytosis at diagnosis in this treatment setting. In the present study, data were collected retrospectively for 222 patients from two different phase II studies conducted between 2002-2007 in Sweden with patients treated with chemoradiotherapy for stage IIIA-IIIB NSCLC. Clinical data and the serum values of hemoglobin (Hgb), White blood cells (WBC) and Platelets (Plt) at enrollment were collected for all patients and studied in relation to overall survival using Kaplan-Meier product-limit estimates and a multivariate Cox proportional hazards regression model. The results showed that patients with thrombocytosis (Plt $>350 \times 10^{9} / \mathrm{L}$ ) had a shorter median overall survival (14.5 months) than patients with normal Plt at baseline (23.7 months). Patients with leukocytosis (WBC $>9 \times 10^{9} / \mathrm{L}$ ) had a shorter median survival (14.9 months) than patients with a normal WBC at baseline (22.5 months). However, in a multivariate model including all lab parameters and clinical factors, only thrombocytosis and performance status displayed a prognostic significance. In Conclusion, thrombocytosis showed to be an independent prognostic marker associated with shorter overall survival in stage III NSCLC treated with curatively intended chemoradiotherapy. This knowledge can potentially be used together with established prognostic factors, such as performance status when choosing the optimal therapy for the individual patient in this clinical setting.
\end{abstract}

Key words: NSCLC, anemia, leukocytosis, thrombocytosis, prognostic, survival

Lung cancer is the leading cause of cancer-related death worldwide [1]. Non-small cell lung cancer (NSCLC) is the most common type of lung cancer accounting for about $85 \%$ of all cases [2]. The prognosis for these patients is poor, partly due to the fact that most patients are diagnosed in a late stage of disease when the tumor has become inoperable. Patients with locally advanced NSCLC (stage III) in a good performance status are usually treated with a combination of radiotherapy and chemotherapy, a treatment with a curative intention but also with considerable and potentially fatal side effects $[3,4]$. Despite receiving this treatment, the 5-year survival rate for stage III NSCLC is only about $15 \%$ [5]. In this situation, the challenge for the clinician is to give the best possible treatment to each individual patient and to avoid unnecessary side effects. Many studies have been conducted concerning prognostic and predictive biomarkers, often driven by the development of biological anti-neoplastic drugs [6]. However, little research has been done concerning clinical prognostic and predictive markers in radical radiotherapy, despite the great need to identify which patients will benefit from this kind of treatment. The Swedish Lung Cancer Study Group has previously conducted retrospective studies of a large cohort of NSCLC patients searching for clinical prognostic factors 
in NSCLC treated with curatively intended radiotherapy [7-9] with results indicating that anemia, leukocytosis and thrombocytosis at diagnosis are negative prognostic markers associated with shorter overall survival[9]. The role of these hematopoietic markers in NSCLC has been reviewed elsewhere in the literature, but with conflicting results and in heterogeneous study populations [10-21]. The aim of the present study was to retrospectively assess the prognostic value of anemia, leukocytosis and thrombocytosis at diagnosis in two cohorts of patients with stage III NSCLC treated with curatively intended chemoradiotherapy between the years 2002-2007 in Sweden.

Table1. Patient characteristics

\begin{tabular}{|c|c|c|c|}
\hline & $\begin{array}{l}\text { All patients } \\
\quad(n=222)\end{array}$ & $\begin{array}{l}\text { Raket study } \\
\text { population } \\
(n=151)\end{array}$ & $\begin{array}{l}\text { Satellit study } \\
\text { population } \\
(n=71)\end{array}$ \\
\hline \multicolumn{4}{|l|}{ Gender } \\
\hline Male & $113(51 \%)$ & $78(52 \%)$ & $35(49 \%)$ \\
\hline Female & $109(49 \%)$ & $73(48 \%)$ & $36(51 \%)$ \\
\hline \multicolumn{4}{|l|}{ Age } \\
\hline$<55$ years & $40(18 \%)$ & $25(17 \%)$ & $15(21 \%)$ \\
\hline 55-64 years & $91(41 \%)$ & $62(42 \%)$ & $29(41 \%)$ \\
\hline $65-74$ years & $74(33 \%)$ & $54(37 \%)$ & $20(28 \%)$ \\
\hline$\geq 75$ years & $14(6.3 \%)$ & $7(4.7 \%)$ & $7(10 \%)$ \\
\hline Missing & $3(1.3 \%)$ & $3(2.0 \%)$ & 0 \\
\hline \multicolumn{4}{|l|}{ Histology } \\
\hline Adenocarcinoma & $107(48 \%)$ & $73(49 \%)$ & $34(49 \%)$ \\
\hline SCC & $75(34 \%)$ & $47(32 \%)$ & $28(40 \%)$ \\
\hline Other & $37(17 \%)$ & $29(20 \%)$ & $8(11 \%)$ \\
\hline Missing & $3(1.3 \%)$ & $2(1.3 \%)$ & $1(1.4 \%)$ \\
\hline \multicolumn{4}{|l|}{$\mathrm{Hgb}$} \\
\hline Anemia & $21(9.5 \%)$ & $11(7.3 \%)$ & $10(14 \%)$ \\
\hline No anemia & $198(89 \%)$ & $137(91 \%)$ & $61(86 \%)$ \\
\hline Missing & $3(1.3 \%)$ & $3(2.0 \%)$ & 0 \\
\hline \multicolumn{4}{|l|}{ WBC } \\
\hline Leukocytosis & $123(55 \%)$ & $78(52 \%)$ & $45(63 \%)$ \\
\hline No leukocytosis & $95(43 \%)$ & $69(46 \%)$ & $26(37 \%)$ \\
\hline Missing & $4(1.8 \%)$ & $4(2.6 \%)$ & 0 \\
\hline \multicolumn{4}{|l|}{ Plt } \\
\hline Thrombocytosis & $123(55 \%)$ & $82(54 \%)$ & $41(58 \%)$ \\
\hline No thrombocytosis & $96(43 \%)$ & $66(44 \%)$ & $30(42 \%)$ \\
\hline Missing & $3(1.3 \%)$ & $3(2.0 \%)$ & 0 \\
\hline \multicolumn{4}{|l|}{ PS } \\
\hline 0 & $123(55.4 \%)$ & $83(55.0 \%)$ & $40(56.3 \%)$ \\
\hline 1 & $99(44.6 \%)$ & $68(45.0 \%)$ & $31(43.7 \%)$ \\
\hline \multicolumn{4}{|l|}{ Weight loss } \\
\hline$\leq 5 \%$ & $133(59.9 \%)$ & $92(60.1 \%)$ & $37(52.1 \%)$ \\
\hline$>5 \%$ & $63(28.4 \%)$ & $41(27.2 \%)$ & $26(36.6 \%)$ \\
\hline Missing & $26(11.7 \%)$ & $18(11.9 \%)$ & $8(11.3 \%)$ \\
\hline \multicolumn{4}{|l|}{ Stage } \\
\hline IIIA & $77(34.7 \%)$ & $51(33.8 \%)$ & $26(36.6 \%)$ \\
\hline IIIB & $145(65.3 \%)$ & $100(66.2 \%)$ & $45(63.4 \%)$ \\
\hline
\end{tabular}

\section{Patients and methods}

Data were collected retrospectively from two different phase II studies evaluating radiotherapy in stage III NSCLC conducted between the years 2002-2007 in Sweden. The first study, the RAKET trial [22], was a three-armed randomized trial of 151 patients with NSCLC stage IIIA/IIIB treated with induction chemotherapy (carboplatin AUC 6/paclitaxel $200 \mathrm{mg} / \mathrm{m}^{2}$ ) followed by either A, hyperfractionated accelerated radiotherapy 1.7 Gy twice-a-day to 64.6 Gy concurrent with a third cycle chemotherapy, B, radiotherapy with $2 \mathrm{~Gy}$ daily to 60 Gy concurrent with daily paclitaxel $12 \mathrm{mg} / \mathrm{m}^{2}$, or C, radiotherapy with 2 Gy daily to 60 Gy concurrent with weekly paclitaxel $60 \mathrm{mg} / \mathrm{m}^{2}$. The second study, the Satellite trial[23], was a one-armed phase II trial of 71 patients with NSCLC stage IIIA/IIIB treated with two cycles of induction chemotherapy (cisplatin $75 \mathrm{mg} / \mathrm{m}^{2} /$ docetaxel $75 \mathrm{mg} / \mathrm{m}^{2}$ ) followed by radiotherapy, 2 Gy daily, to 68 Gy concurrent with weekly cetuximab (initial dose of $400 \mathrm{mg} / \mathrm{m}^{2}$ followed by $250 \mathrm{mg} / \mathrm{m}^{2}$ ). In total these trials compose a pooled dataset of 222 patients available for analysis. Data regarding gender, age at diagnosis, histology (defined as squamous cell carcinoma, adenocarcinoma or other non-small cell lung cancer), performance status, weight loss, stage and the serum values of hemoglobin (Hgb), white blood cells (WBC) and platelets (Plt) at enrollment were collected for all patients and studied in relation to overall survival. The reference limits for thrombocytosis (Plt $>350 \times 10^{9} / \mathrm{L}$ ) and leukocytosis (WBC $>9 \times 10^{9} / \mathrm{L}$ ) were taken from the normal intervals used at the Uppsala University Hospital. The lower Hgb limit is different in men and women. However, we decided to use $<110 \mathrm{~g} / \mathrm{L}$ as the limit for anemia in both genders as have been done previously[9].

Statistics. Standard descriptive statistics were used to present patients' characteristics at diagnosis. Overall survival was analyzed with Kaplan-Meier product-limit estimates and survival curves for the different categories of patients were compared using the log-rank test. Follow-up time was calculated from the date of enrollment to the date of death or last follow-up date. Age was defined as age at diagnosis and categorized into age groups as have been reported previously[8] as well as analyzed as a variable. Overall survival was also analyzed using a multivariate Cox proportional hazards regression model. The multivariate model was adjusted by gender, age at diagnosis, Hgb, WBC and Plt. Results were presented as hazard ratios with $95 \%$ confidence intervals (95\% CI) and with $p$-values where $p<0.05$ was considered statistically significant.

\section{Results}

Of the 222 patients available for analysis, 113 (51\%) were men. The median age was 62 years (range: $42-81$ years). Histologically, 107 patients (48\%) had adenocarcinoma (AC), 75 patients (34\%) had squamous cell carcinoma (SCC) and 
37 (17\%) had other histopathological features. The median value of $\mathrm{Hgb}$ at baseline was $130 \mathrm{~g} / \mathrm{L}$ (range 88-165 g/L) and $21(9.5 \%)$ patients were defined as being anemic ( $\mathrm{Hgb}<$. $110 \mathrm{~g} / \mathrm{L})$. For $\mathrm{WBC}$ the median baseline value was $9.7 \times 10^{9} / \mathrm{L}$ (range 3.8-32.6 $\times 10^{9} / \mathrm{L}$ ) and $123(55 \%)$ of patients had by this definition leukocytosis (WBC $>9 \times 10^{\%} / \mathrm{L}$ ). For Plt the median value at baseline was $367 \times 10^{9} / \mathrm{L}$ (range $139-868 \times 10^{9} / \mathrm{L}$ ) and $123(55 \%)$ of patients had by this definition thrombocytosis (Plt $>.350 \times 10^{9} / \mathrm{L}$ ). Concerning WHO Performance status, 123 patients (55.4\%) were considered to be in PS 0, whereas the other 99 patients (44.6\%) were considered to be in PS 1. A pre-treatment weight loss of $>5 \%$ was observed in $63 \mathrm{pa}-$ tients $(28.3 \%)$. The included patients were either in clinical disease stage IIIA $(34.7 \%)$ or stage IIIB (65.3\%). For a summary of patient characteristics, see Table 1 .
The median overall survival for all patients was 17.7 months and the median survival was similar in the RAKET study, 17.8 months, as compared with the Satellite study, 17.0 months. Male patients had a tendency towards shorter median overall survival than female patients (15.8 vs. 20.6 months), a difference that was not statistically significant $(\mathrm{p}=0.11, \log$-rank test). Patients with AC histology had a median overall survival of 20.1 months which was superior to patients with SCC and other histology (18.2 and 13.0 months, respectively), a difference which was not statistically significant ( $\mathrm{p}=0.099, \log$-rank test). Patients with PS 0 had a better median overall survival than patients with PS 1 (22.5 and 14.9 months, respectively), a difference which was statistically significant ( $p=0.0015$, log-rank test). Patients in disease stage IIIB had a slightly better overall survival than

A

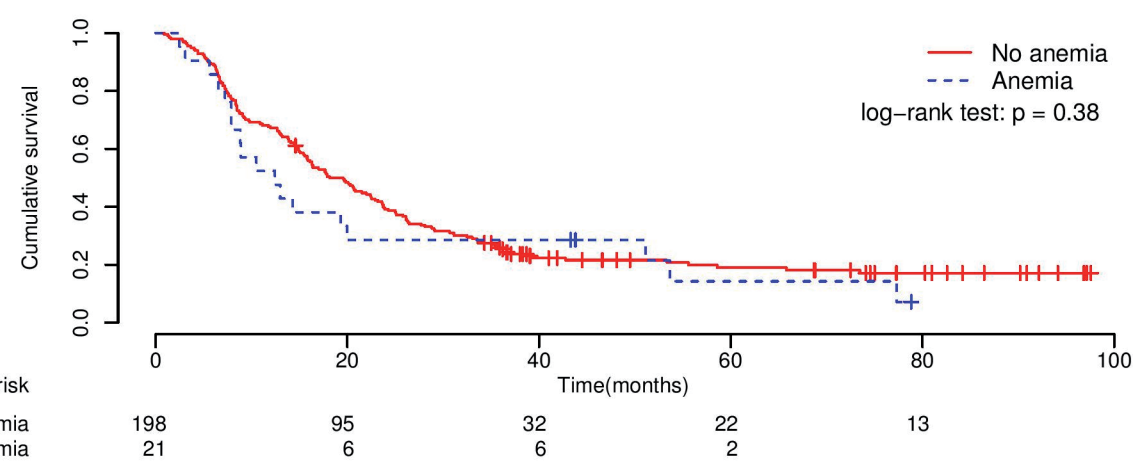

B

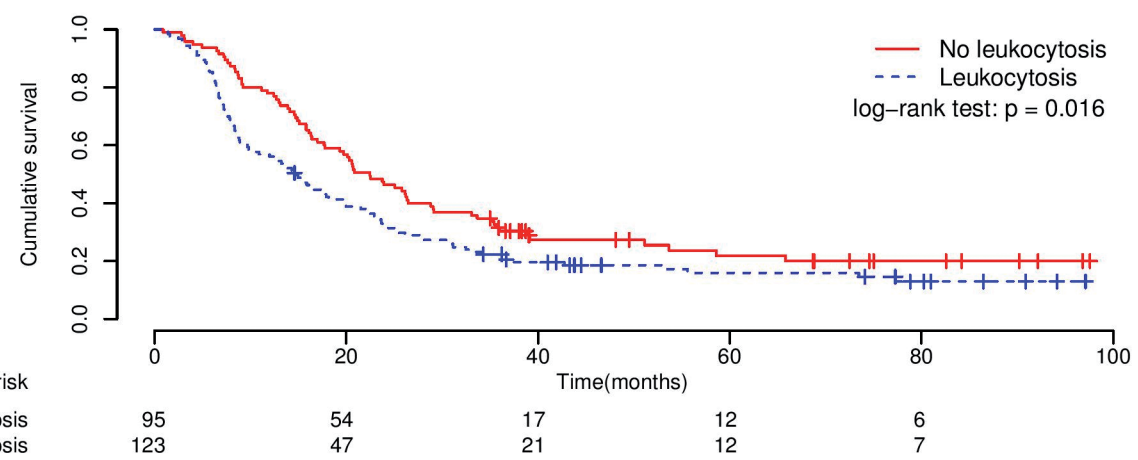

C

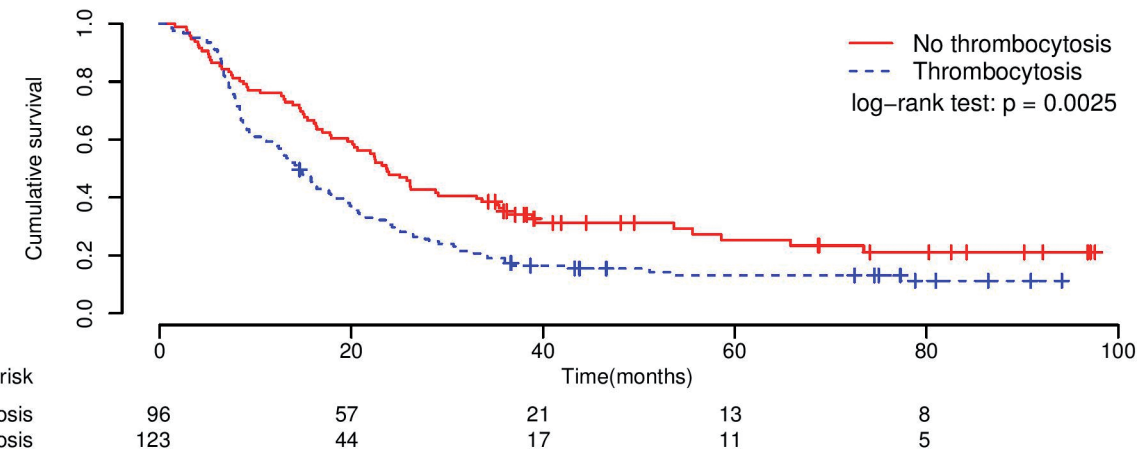

Figure 1. Hematopoietic lab abnormalities and survival 


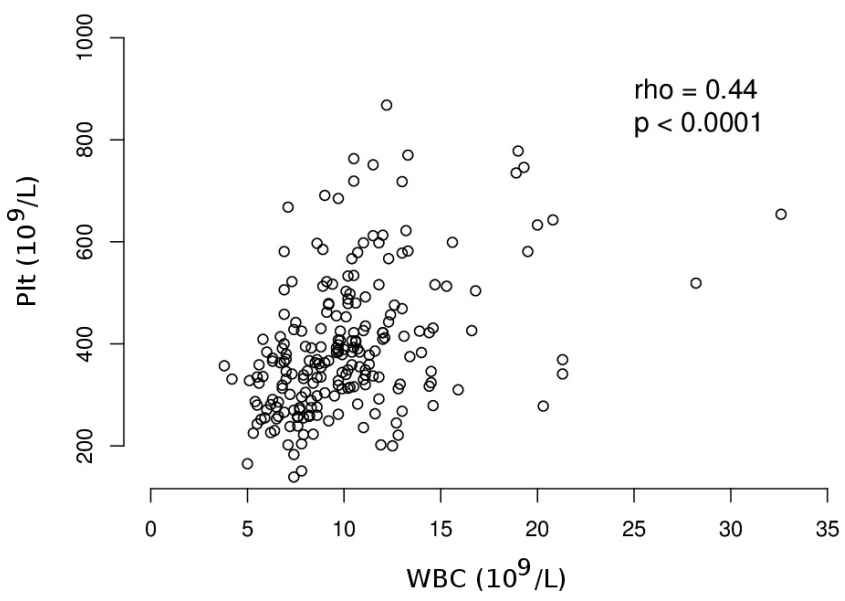

Figure 2. Association between leukocytosis and thrombocytosis

Table 2. Median overall survival for different subgroups

\begin{tabular}{|c|c|c|}
\hline & $\begin{array}{l}\text { Median overall survival } \\
(95 \% \mathrm{CI}) \text { in months }\end{array}$ & $\begin{array}{c}\text { p-value } \\
(\log \text {-rank test })\end{array}$ \\
\hline All patients & $17.7(15.1-21.5)$ & - \\
\hline \multicolumn{3}{|l|}{ Study population } \\
\hline Raket & $17.8(14.9-22)$ & \\
\hline Satellit & $17.0(14.7-25)$ & 0.31 \\
\hline \multicolumn{3}{|l|}{ Gender } \\
\hline Male & $15.8(13.0-20.3)$ & \\
\hline Female & $20.6(16.3-26.3)$ & 0.11 \\
\hline \multicolumn{3}{|l|}{ Age } \\
\hline$<55$ years & $21.5(15.5-27.7)$ & \\
\hline $55-64$ years & $16.3(12.7-26.1)$ & \\
\hline $65-74$ years & $16.9(13.8-22.9)$ & \\
\hline$\geq 75$ years & $21.4(8.9-\mathrm{NA})$ & 0.99 \\
\hline \multicolumn{3}{|l|}{ Histology } \\
\hline Adenocarcinoma & $20.1(15.8-25.0)$ & \\
\hline $\begin{array}{l}\text { Squamous cell } \\
\text { carcinoma }\end{array}$ & $18.2(13.9-26.3)$ & \\
\hline Other & $13.0(7.3-19.6)$ & 0.099 \\
\hline \multicolumn{3}{|l|}{ Performance Status } \\
\hline 0 & $22.5(17.8-29.1)$ & \\
\hline 1 & $14.9(9.8-19.3)$ & 0.0015 \\
\hline \multicolumn{3}{|l|}{ Stage } \\
\hline IIIA & $16.4(14.1-25.1)$ & \\
\hline IIIB & $17.9(14.9-22.5)$ & 0.68 \\
\hline \multicolumn{3}{|l|}{ Weight loss } \\
\hline$\leq 5 \%$ & $20.6(16.4-25.1)$ & \\
\hline$>5 \%$ & $13.6(8.9-20.6)$ & 0.061 \\
\hline \multicolumn{3}{|l|}{$\mathrm{Hgb}$} \\
\hline Anemia & $12.5(7.9-53.7)$ & \\
\hline No anemia & $18.2(15.9-22.9)$ & 0.38 \\
\hline \multicolumn{3}{|l|}{ WBC } \\
\hline Leukocytosis & $14.9(10.5-19.8)$ & \\
\hline No leukocytosis & $22.5(17.8-29.0)$ & 0.016 \\
\hline \multicolumn{3}{|l|}{ Plt } \\
\hline Thrombocytosis & $14.5(12.0-18.2)$ & \\
\hline No thrombocytosis & $23.7(20.1-33.6)$ & 0.0025 \\
\hline
\end{tabular}

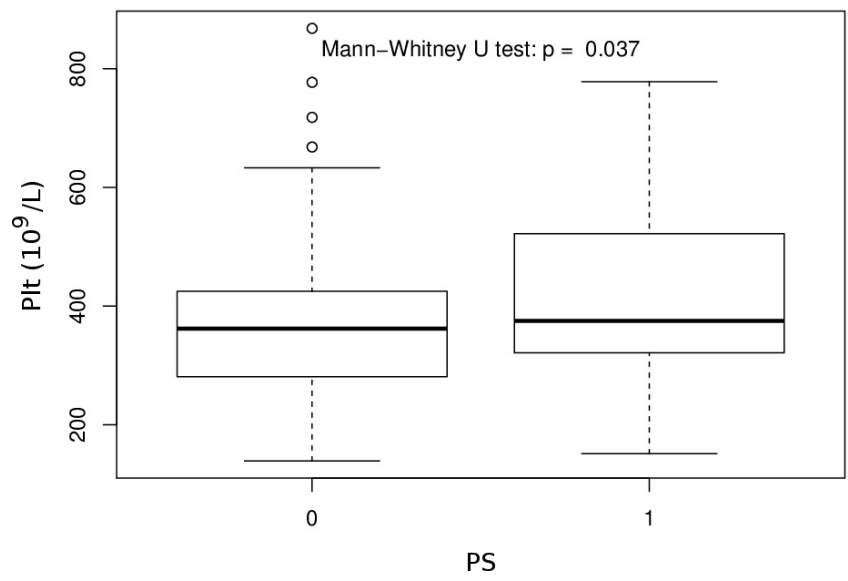

Figure 3. Association between PS and thrombocytosis illustrated with a Tukey's boxplot

patients in stage IIIA (17.9 and 16.4 months, respectively), but the difference was not statistically significant $(\mathrm{p}=0.68$, log-rank test). Patients with pre-treatment weight loss of $>5 \%$ had a shorter median survival than patients with weight loss $\leq 5 \%$ (13.6 and 20.6 months, respectively), a difference that did not reach statistical significance ( $p=0.061$, log-rank test).

When comparing patients with and without anemia (Figure 1A), the patients with anemia had a shorter median survival (12.5 months) as compared with the patients without anemia (18.2 months). The difference was not statistically significant ( $p=0.39$, log rank test). For patients with and without leukocytosis (Figure 1B), the patients with leukocytosis had a shorter median survival (14.9 months) as compared with the patients with a normal WBC at baseline (22.5 months). The difference was statistically significant $(p=0.016, \log$ rank test). Furthermore, for patients with and without thrombocytosis (Figure 1C), the patients with thrombocytosis had a shorter median survival (14.5 months) as compared with the patients with normal Plt at baseline (23.7 months). The difference was statistically significant $(\mathrm{p}=0.0025$, log rank test). For a summary of median overall survival in different categories of patients see Table 2. It was found that the values of WBC and Plt correlated with a Spearman's correlation coefficient of $0.44(\mathrm{p}<0.0001)$ meaning that patients with high WBC levels were more likely to also have high Plt levels (Figure 2). Also, as shown in Figure 3, higher Plt levels were seen in patients with PS 1 as compared with patients with PS 0 ( $\mathrm{p}=0.037$, Mann-Whitney's test). In a multivariate Cox analysis (Table 3 ) including clinical data and all three pathological lab parameters the prognostic significance was still evident for PS (HR: 1.61, 95\% CI: 1.15-2.26, p = 0.0051) and thrombocytosis (HR: 1.66, 95\% CI: 1.12-2.48, p = 0.012) whereas leukocytosis was no longer significantly associated with worse overall survival (HR: 1.09, 95\% CI: 0.75-1.58, p = 0.64). Due to missing data, 11 patients were excluded from the multivariate analysis. 


\section{Discussion}

In the present study we have analyzed the relationship between the standard hematopoietic blood parameters $\mathrm{Hgb}, \mathrm{WBC}$ and Plt at diagnosis and overall survival in two cohorts including 222 patients with NSCLC treated with curatively intended chemoradiotherapy. Our findings show that there is a statistically significant independent association between thrombocytosis at diagnosis and shorter overall survival in both univariate and multivariate analyses. The negative prognostic impact of thrombocytosis on survival is comparable with having a WHO Performance status of 1 as compared with PS 0 . For leukocytosis a similar relationship is seen in a univariate analysis but not in a multivariate analysis when other factors such as performance status are taken into consideration. For anemia, no relationship with survival is found although the results are difficult to interpret due to the low number of patients with anemia in the two cohorts.

The prognostic value of standard hematopoietic blood parameters in NSCLC has received scant interest and many of the previous studies included small and heterogeneous study populations. The strengths of the present study are the relatively large number of clearly defined and similarly treated patients; stage III NSCLC in good performance status (0-1) treated with curatively intended chemoradiotherapy. However, the study also has some limitations including its retrospective nature and that the data come from two separate cohorts with slightly differently treated patient populations. Also, stage III NSCLC consists of a heterogeneous population of lesions (i.e., T4N0-3, T3N1-3, and T1a-2aN2-3) and the prognostic significance of the blood parameters examined may differ between these entities. Furthermore, other factors affecting the values of the examined hematopoietic blood parameters such as infections, inflammatory diseases and medications have not been taken into consideration.

A mechanism of elevated thrombocyte count affecting the blood vessel endothelium leading to facilitation of cell invasion and metastasis has been suggested[24] and thrombocytosis has, similarly to leukocytosis, been shown to be a negative prognostic marker in NSCLC in several studies [12, 16-20]. Lately, the neutrophil-to-lymphocyte ratio (NLR) and the platelet-to-lymphocyte ratio (PLR) have been shown to be a prognostic factor for survival in several solid tumors, including NSCLC $[25,26]$. In a study by Unal et al. of 94 patients with non-metastatic NSCLC who underwent chemoradiotherapy, pretreatment high NLR and PLR were both associated with shorter disease-free and overall survival rates. In a multivariate analysis, overall survival was significantly associated with high PLR whereas disease-free survival was significantly associated with high NLR [27]. In a retrospective study of 59 patients with stage I NSCLC treated with stereotactic radiotherapy, high PLR was significantly associated with a higher non-local failure rate as compared with low PLR in a multivariate analysis $(58 \%$ as compared with $11 \%$ ) [28].
The impact of pretreatment anemia for NSCLC patients is controversial. In accordance with the present study, the results from a large study of over 2500 NSCLC patients by Albain et al. [29] showed no correlation between anemia and survival in the entire NSCLC population. However, there are also some reports of pre-treatment low $\mathrm{Hgb}$ as an independent prognostic factor for survival in NSCLC $[30,31]$. Leukocytosis in patients with cancer is usually caused by infection or bone marrow metastases. However, in some cases elevated WBC is seen in absence of other signs of infectious disease and is considered to be paraneoplastic, caused mainly by abnormal production of hematopoietic cytokines by the tumor of which more than 40 have been identified to this date [32]. Several studies, including a pooled analysis of North Central Cancer Treatment Group (NCCTG) trials with data from over 1000 patients, have reported leukocytosis to be associated with poorer outcome in NSCLC $[12,14,15,21,31]$.

However, previous studies have either been focused on advanced/metastatic NSCLC or leukocytosis and thrombocytosis

Table 3. Multivariate Cox analysis of overall survival

\begin{tabular}{|c|c|c|c|}
\hline & $\begin{array}{c}\text { Hazard ratio } \\
(95 \% \mathrm{CI})\end{array}$ & $\begin{array}{c}\text { Standard } \\
\text { error }\end{array}$ & p-value \\
\hline \multicolumn{4}{|l|}{ Gender } \\
\hline Female (ref) & - & - & - \\
\hline Male & $1.30(0.91-1.83)$ & 0.18 & 0.14 \\
\hline \multicolumn{4}{|l|}{ Age } \\
\hline$<55$ years $($ ref $)$ & - & - & - \\
\hline 55-64 years & $1.16(0.74-1.81)$ & 0.23 & 0.53 \\
\hline $65-74$ years & $1.19(0.75-1.90)$ & 0.24 & 0.46 \\
\hline$\geq 75$ years & $1.14(0.53-2.45)$ & 0.39 & 0.74 \\
\hline \multicolumn{4}{|l|}{ Histology } \\
\hline SCC (ref) & - & - & - \\
\hline $\mathrm{AC}$ & $1.05(0.72-1.52)$ & 0.19 & 0.81 \\
\hline Other & $1.39(0.86-2.24)$ & 0.24 & 0.18 \\
\hline \multicolumn{4}{|l|}{ Performance status } \\
\hline 0 (ref) & - & - & - \\
\hline 1 & $1.61(1.15-2.26)$ & 0.17 & 0.0051 \\
\hline \multicolumn{4}{|l|}{ Weight loss (> 5\%) } \\
\hline No (ref) & - & - & - \\
\hline Yes & $1.05(0.73-1.51)$ & 0.18 & 0.79 \\
\hline \multicolumn{4}{|l|}{ Stage } \\
\hline IIIA (ref) & - & - & - \\
\hline IIIB & $0.91(0.64-1.29)$ & 0.18 & 0.59 \\
\hline \multicolumn{4}{|l|}{ Hgb } \\
\hline No Anemia (ref) & - & - & - \\
\hline Anemia & $0.98(0.56-1.73)$ & 0.29 & 0.95 \\
\hline \multicolumn{4}{|l|}{ WBC } \\
\hline No Leukocytosis (ref) & - & - & - \\
\hline Leukocytosis & $1.09(0.75-1.58)$ & 0.19 & 0.64 \\
\hline \multicolumn{4}{|l|}{ Plt } \\
\hline No thrombocytosis (ref) & - & - & - \\
\hline Thrombocytosis & $1.66(1.12-2.48)$ & 0.2 & 0.012 \\
\hline
\end{tabular}

Model including gender, age at diagnosis, histology, performance status, weight loss, stage, $\mathrm{Hgb}, \mathrm{WBC}$ and Plt; number of observations used $=211$; missing due to lack of data $=11$ 
have not been analyzed together in multivariate models that include established prognostic factors such as performance status. Thus, their prognostic significance in the setting of curatively intended chemoradiotherapy for NSCLC remains unclear. Notably, in the present study leukocytosis was shown to be a prognostic marker of shorter overall survival when analyzed on its own but not when other factors such as thrombocytosis and performance status were taken into account in a multivariate analysis. Considering the high correlation between leukocytosis and thrombocytosis, it is possible to hypothesize that leukocytosis is associated with thrombocytosis as a marker of inflammation, but leukocytosis per se is not associated with worse prognosis in NSCLC. Interestingly, while thrombocytosis also correlates with worse performance status, both factors are independently associated with shorter median survival with similar hazard ratios in a multivariate analysis.

In conclusion, of the three standard hematopoietic lab abnormalities studied here, thrombocytosis seems to have the highest prognostic significance and to be associated with shorter overall survival in stage III NSCLC treated with curatively intended chemoradiotherapy. Further studies are required to fully assess the prognostic value of thrombocytosis and to find ways to integrate it with established prognostic factors such as performance status and disease stage, when choosing the optimal therapy for the individual patient.

\section{References}

[1] TORRE LA, BRAY F, SIEGEL RL, FERLAY J, LORTETTIEULENT J et al. Global cancer statistics, 2012. CA Cancer J Clin 2015; 65: 87-108. https://doi.org/10.3322/caac.21262

[2] GOVINDAN R, PAGE N, MORGENSZTERN D, READ W, TIERNEY R et al. Changing epidemiology of small-cell lung cancer in the United States over the last 30 years: analysis of the surveillance, epidemiologic, and end results database. J Clin Oncol 2006; 24: 4539-4544. https://doi.org/10.1200/ JCO.2005.04.4859

[3] BAYMAN N, BLACKHALL F, MCCLOSKEY P, TAYLOR P, FAIVRE-FINN C. How can we optimise concurrent chemoradiotherapy for inoperable stage III non-small cell lung cancer? Lung Cancer 2014; 83: 117-125. https://doi.org/10.1016/j. lungcan.2013.11.017

[4] SALAMA JK, STINCHCOMBE TE, GU L, WANG X, MORANO K et al. Pulmonary toxicity in Stage III non-small cell lung cancer patients treated with high-dose (74 Gy) 3-dimensional conformal thoracic radiotherapy and concurrent chemotherapy following induction chemotherapy: a secondary analysis of Cancer and Leukemia Group B (CALGB) trial 30105. Int J Radiat Oncol Biol Phys 2011; 81: e269-274. https://doi.org/10.1016/j.ijrobp.2011.01.056

[5] AUPERIN A, LE PECHOUX C, ROLLAND E, CURRAN WJ, FURUSE K et al. Meta-analysis of concomitant versus sequential radiochemotherapy in locally advanced non-small-cell lung cancer. Journal of clinical oncology: J Clin Oncol 2010; 28: 2181-2190. https://doi.org/10.1200/JCO.2009.26.2543
[6] SATO M, SHAMES DS, GAZDAR AF, MINNA JD. A translational view of the molecular pathogenesis of lung cancer. J Thorac Oncol 2007; 2: 327-343. https://doi.org/10.1097/01. JTO.0000263718.69320.4c

[7] HOLGERSSON G, BERGSTROM S, BERGQVIST M, NYMAN J, HOYE E et al. Swedish lung cancer radiation study group: predictive value of histology for radiotherapy response in patients with non-small cell lung cancer. Eur J Cancer 2011; 47: 2415-2421. https://doi.org/10.1016/j.ejca.2011.06.011

[8] HOLGERSSON G, HOYE E, BERGQVIST M, EKMAN S, NYMAN J et al. Swedish Lung Cancer Radiation Study Group: predictive value of age at diagnosis for radiotherapy response in patients with non-small cell lung cancer. Acta Oncol 2012; 51: 759-767. https://doi.org/10.3109/028418 $\underline{6 X .2012 .681064}$

[9] HOLGERSSON G, SANDELIN M, HOYE E, BERGSTROM $S$, HENRIKSSON R et al. Swedish lung cancer radiation study group: the prognostic value of anaemia, thrombocytosis and leukocytosis at time of diagnosis in patients with non-small cell lung cancer. Med Oncol 2012; 29: 3176-3182. https://doi. org/10.1007/s12032-012-0247-3

[10] CHAMOGEORGAKIS T, ANAGNOSTOPOULOS C, KOSTOPANAGIOTOU G, BHORA F, TOUMPOULIS I et al. Does anemia affect outcome after lobectomy or pneumonectomy in early stage lung cancer patients who have not received neo-adjuvant treatment? Thorac Cardiovasc Surg 2008; 56: 148-153. https://doi.org/10.1055/s-2007-989455

[11] TOMITA M, SHIMIZU T, HARA M, AYABE T, ONITSUKA T. Impact of preoperative hemoglobin level on survival of non-small cell lung cancer patients. Anticancer Res 2008; 28: 1947-1950.

[12] GISLASON T, NOU E. Sedimentation rate, leucocytes, platelet count and haemoglobin in bronchial carcinoma: an epidemiological study. Eur J Respir Dis 1985; 66: 141-146.

[13] MACRAE R, SHYR Y, JOHNSON D, CHOY H. Declining hemoglobin during chemoradiotherapy for locally advanced non-small cell lung cancer is significant. Radiother Oncol 2002; 64: 37-40. https://doi.org/10.1016/ $\underline{\text { S0167-8140(02)00151-2 }}$

[14] KASUGA I, MAKINO S, KIYOKAWA H, KATOH H, EBIHARA Y et al. Tumor-related leukocytosis is linked with poor prognosis in patients with lung carcinoma. Cancer 2001; 92: 2399-2405. https://doi.org/10.1002/10970142(20011101)92:9<2399::AID-CNCR1588>3.0.CO;2-W

[15] FERRIGNO D, BUCCHERI G. Hematologic counts and clinical correlates in 1201 newly diagnosed lung cancer patients. Monaldi Arch Chest Dis 2003; 59: 193-198.

[16] TOMITA M, SHIMIZU T, HARA M, AYABE T, ONITSUKA T. Prognostic impact of thrombocytosis in resectable nonsmall cell lung cancer. Interact Cardiovasc Thorac Surg 2008; 7: 613-615. https://doi.org/10.1510/icvts.2007.174391

[17] ENGAN T, HANNISDAL E. Blood analyses as prognostic factors in primary lung cancer. Acta Oncol 1990; 29: 151-154. https://doi.org/10.3109/02841869009126536

[18] PEDERSEN LM, MILMAN N. Prognostic significance of thrombocytosis in patients with primary lung cancer. Eur RespirJ 1996; 9: 1826-1830. https://doi.org/10.1183/09031936.96.09091826 
[19] AOE K, HIRAKI A, UEOKA H, KIURA K, TABATA M et al. Thrombocytosis as a useful prognostic indicator in patients with lung cancer. Respiration 2004; 71: 170-173. https://doi. org/10.1159/000076679

[20] KIM KH, PARK TY, LEE JY, LEE SM, YIM JJ et al. Prognostic significance of initial platelet counts and fibrinogen level in advanced non-small cell lung cancer. J Korean Med Sci 2014; 29: 507-511. https://doi.org/10.3346/jkms.2014.29.4.507

[21] TIBALDI C, VASILE E, BERNARDINI I, ORLANDINI C, ANDREUCCETTI M et al. Baseline elevated leukocyte count in peripheral blood is associated with poor survival in patients with advanced non-small cell lung cancer: a prognostic model. J Cancer Res Clin Oncol 2008; 134: 1143-1149. https://doi. org/10.1007/s00432-008-0378-2

[22] NYMAN J, FRIESLAND S, HALLQVIST A, SEKE M, BERGSTROM S et al. How to improve loco-regional control in stages IIIa-b NSCLC? Results of a three-armed randomized trial from the Swedish Lung Cancer Study Group. Lung Cancer 2009; 65: 62-67. https://doi.org/10.1016/j.lungcan.2008.10.021

[23] HALLQVIST A, WAGENIUS G, RYLANDER H, BRODIN O, HOLMBERG E et al. Concurrent cetuximab and radiotherapy after docetaxel-cisplatin induction chemotherapy in stage III NSCLC: satellite--a phase II study from the Swedish Lung Cancer Study Group. Lung Cancer 2011; 71: 166-172. https:// doi.org/10.1016/j.lungcan.2010.05.011

[24] MEHTA P. Potential role of platelets in the pathogenesis of tumor metastasis. Blood 1984; 63: 55-63.

[25] TEMPLETONAJ, ACEO, MCNAMARA MG, AL-MUBARAK M, VERA-BADILLO FE et al. Prognostic role of platelet to lymphocyte ratio in solid tumors: a systematic review and meta-analysis. Cancer Epidemiol Biomarkers Prev 2014; 23 : 1204-1212. https://doi.org/10.1158/1055-9965.EPI-14-0146

[26] TEMPLETON AJ, MCNAMARA MG, SERUGA B, VERA-BADILLO FE, ANEJA P et al. Prognostic role of neutrophil-to-lymphocyte ratio in solid tumors: a systematic review and meta-analysis. J Natl Cancer Inst 2014; 106: dju124. https://doi.org/10.1093/jnci/dju124

[27] UNAL D, EROGLU C, KURTUL N, OGUZ A, TASDEMIR A. Are neutrophil/lymphocyte and platelet/lymphocyte rates in patients with non-small cell lung cancer associated with treatment response and prognosis? Asian Pac J Cancer Prev 2013; 14: 5237-5242. https://doi.org/10.7314/ APJCP.2013.14.9.5237

[28] CANNON NA, MEYER J, IYENGAR P, AHN C, WESTOVER KD et al. Neutrophil-lymphocyte and platelet-lymphocyte ratios as prognostic factors after stereotactic radiation therapy for early-stage non-small-cell lung cancer. J Thorac Oncol 2015; 10: 280-285. https://doi.org/10.1097/ JTO.0000000000000399

[29] ALBAIN KS, CROWLEY JJ, LEBLANC M, LIVINGSTON RB. Survival determinants in extensive-stage non-small-cell lung cancer: the Southwest Oncology Group experience. J Clin Oncol 1991; 9: 1618-1626. https://doi.org/10.1200/ LCO.1991.9.9.1618

[30] HSU CL, CHEN KY, SHIH JY, HO CC, YANG CH et al. Advanced non-small cell lung cancer in patients aged 45 years or younger: outcomes and prognostic factors. BMC Cancer 2012; 12: 241. https://doi.org/10.1186/1471-2407-12-241

[31] MANDREKAR SJ, SCHILD SE, HILLMAN SL, ALLEN KL, MARKS RS et al. A prognostic model for advanced stage nonsmall cell lung cancer. Pooled analysis of North Central Cancer Treatment Group trials. Cancer 2006; 107: 781-792. https://doi.org/10.1002/cncr.22049

[32] MAIONE P, ROSSI A, DI MAIO M, GRIDELLI C. Tumorrelated leucocytosis and chemotherapy-induced neutropenia: linked or independent prognostic factors for advanced nonsmall cell lung cancer? Lung Cancer 2009; 66: 8-14. https:// doi.org/10.1016/j.lungcan.2009.02.022 